\title{
Frequency and Predictors of Potential Drug - Drug Interactions in Hospitalized Patients With Parkinson's Diseases
}

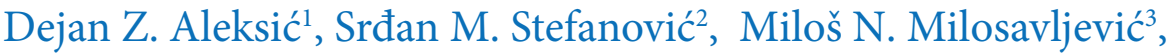 \\ Jovana Z. Milosavljevićc ${ }^{4}$ Slobodan M. Janković ${ }^{3}$ \\ ${ }^{1}$ University of Kragujevac, Faculty of Medical Sciences, Department of Neurology, Kragujevac, \\ Serbia \\ ${ }^{2}$ University of Kragujevac, Faculty of Medical Sciences, Department of Pharmacy, Kragujevac, \\ Serbia \\ ${ }^{3}$ University of Kragujevac, Faculty of Medical Sciences, Department of Pharmacology and \\ Toxicology, Kragujevac, Serbia \\ ${ }^{4}$ University of Kragujevac, Faculty of Medical Sciences, Department of Anatomy, Kragujevac, \\ Serbia
}

\section{SUMMARY}

Introduction: Patients with Parkinson's disease are exposed to higher number of drugs on average than other elderly persons. Levodopa, of the mainstay of Parkinson's disease therapy, is frequently interacting with numerous drugs.

Aim: The aim of this study was to identify predictors of potential drug-drug interactions (pDDIs) in hospitalized patients suffering from Parkinson's disease (PD).

Material and Methods: This was a academic retrospective cross-sectional study in PD patients hospitalized at the Clinic of Neurology, Clinical Center Kragujevac. Medical records of hospitalized patients during the period 1.1.2017 - 31.12.2019 were analysed. The pDDIs were identified by means of Micromedex andLexi-Interact online softwares, and multivariate regression methods were used to reveal potential predictors of number of pDDls per patient.

Results: Micromedex detected 160 different pDDIs in $77.8 \%$ of 72 patients with PD. The most frequent pDDIs were those that involved aspirin (with bisoprolol, sertraline and perindopril). Predictors of pDDls in general was total number of drugs, while use of antidepressants presented a significant risk factor for major pDDls. Lexi-Interact revealed 310 pDDls in $98.6 \%$ of patients. The three most common pDDls were with levodopa (bisoprolol, clonazepam, perindopril). Total number of drugs, number of co-morbidities, hospitalization at the neurodegenerative ward, and use of antipsychotics were identified as the relevant predictors of pDDIs. Lexi-interact software detected significantly more pDDIs than Micromedex $(p<0.001)$.

Conclusion: Neurologists should pay special attention when deciding whether to administer new drug to a PD patient with multiple comorbidities, hospitalized in a neurodegenerative ward and/or taking antidepressant or antipsychotic drugs.

Keywords: Parkinson's Disease, Potential Drug-Drug Interactions, Predictors, Micromedex, Lexi-Interact 


\section{INTRODUCTION}

Patients with Parkinson's disease (PD) are exposed to higher number of drugs on average than other elderly persons because apart from chronic non-communicable diseases that usually go with advanced age they need several drugs for controlling symptoms of the disease itself $[1,2]$. The conventional pharmacotherapy of Parkinson's disease includes a variety of drugs that act by different mechanisms with the common outcome - increase in the level and activity of dopamine in central nervous system (CNS) (levodopa combined with DOPA decarboxylase inhibitors, dopamine agonists, catechol-O-methyltransferase (COMT) inhibitors, monoamine oxidase $\mathrm{B}$ (MAO-B) inhibitors, etc.) [3]. Since PD is usually associated with a number of physical and mental disorders, especially in the elderly, favoring the simultaneous use of many other drugs, such as cardiovascular drugs, antidiabetic drugs, psychotropic drugs (i.e. antipsychotics, antidepressants, sedatives, anti-dementia drugs), analgesics, antibiotics, etc., drug-drug interactions are likely to occur [4].

Drug-drug interactions represent the changes in the effects of one drug which occur as a consequence of concomitant therapy with another drug. Contraindicated and major interactions to be avoided have the greatest clinical relevance, although moderate interactions also should be monitored with extreme caution [5]. Nowadays, potential drug-drug interactions (pDDIs) could be detected by online checkers such as Micromedex ${ }^{\oplus}$ [6], LexiInteract [7], Medscape [8], Epocrates [9], etc. Numerous potential drug-drug interactions (pDDIs) interactions of antiparkinsonian medications are well-known. Levodopa is prone to pharmacokinetic interactions at the level of absorption (neutral amino acids, antacids, proton pump inhibitors and iron preparations), distribution (aromatic amino acid decarboxylase inhibitors) or metabolism (MAO and COMP inhibitors) [10]. Particularly serious are potential interactions of levodopa with MAO inhibitors, whose simultaneous use should be avoided due to the high risk of hypertensive crisis [11]. Due to pDDIs, concomitant use of antiparkinsonian drugs with diuretics and calcium channel blockers in patients with PD and associated hypertension is certainly not desirable [12]. Also, possible occurrence of serotonin syndrome is the reason why selegiline should not be used concomitantly with fluoxetine and tricyclic antidepressants $[13,14]$.

Certain risk factors for occurrence of pDDIs in hospitalized patients were previously recognized, such as higher number of prescribed medications, longer duration of hospitalization and comorbidity $[5,15,16]$. However, to our best knowledge there are no published studies that have investigated potential drugdrug interactions in patients with PD. Therefore, this study was aimed at determining the prevalence and risk factors for each category of pDDIs in hospitalized patients with PD.

\section{MATERIAL AND METHODS}

\section{Ethical principles}

This research was approved by Ethics Committee of Clinical Center Kragujevac (CCK) (No.01/14886).

\section{Study design and setting, patients and data collection}

This study was designed as an academic retrospective cross-sectional study in $\mathrm{PD}$ patients admitted to the Clinic of Neurology, Clinical Center Kragujevac (CCK). We reviewed medical records of patients with PD who were hospitalized during the period 1.1.2017 - 31.12.2019.

Inclusion criteria were diagnosis of PD and patients with two or more prescribed drugs during the hospitalization. The study also included patients hospitalized for another reason unrelated to PD if they had been previously diagnosed with the disease. The only exclusion criterion was death of a patient during hospitalization.

The following data were collected from the patient medical files: demographic characteristics (gender and age in years), characteristics of hospitalization (reason for hospitalization, ward where the patient was treated (neurological intensive care unit (NICU) or department for neurodegenerative disease), length of hospitalization (in days)), clinical characteristics of PD (bradykinesia, muscular rigidity, resting tremor, postural instability, duration of disease in years), non-motor symptoms and signs of PD (cognitive impairment, pain, falls, uro- 
genital dysfunction, orthostatic hypotension, sleep disorder, constipation, hallucinations), comorbidities (hypertension (HTA), other cardiovascular diseases (coronary artery disease, arrhythmia, valve disease, heart failure), diabetes mellitus 2 (DM2), drug-related allergies, thyroid disorder), laboratory parameters during the first day of hospitalization (glycaemia, creatinine, urine ketone bodies) and characteristics of prescribed drugs (number of drugs, pharmacological group of drugs such as antiplatelet drugs, antihypertensive drugs, antidepressants, antipsychotics, antacids, antiparkinsonian drugs, ...).

\section{Identificiation and classification of the potential drug-drug interactions}

The potential drug-drug interactions (pDDIs) from medical files were identified by online interaction checker softwares Micromedex ${ }^{\otimes}[6]$ and Lexi-Interact [7]. Micromedex 2.0 classifies pDDIs into 4 categories according to severity (contraindicated, major, moderate, minor) and in 3 categories according to scientific evidence (excellent, good, fair). Lexi-Interact interaction checker recognizes the following categories of pDDIs: combination of drugs to be avoided (x), major (d), pDDIs which require monitoring of therapy (c), interactions with no action needed (b) and without evidence of interaction (N/A). According to scientific documentation, thisese checker divides the pDDIs into those with excellent, good, fair and poor evidence. After the pDDIs were recorded, additional variables were determined: number of pDDIs discovered by both checkers as well as the number of pDDIs by category with respect to severity and scientific documentation. The proportion of patients who were exposed to each type of pDDIs, the frequency of each individual pDDIs and type of pDDI were the most frequent were also determined.

\section{Statistical analysis}

Descriptive data were summarized as percentages, median with interquartile rank and mean with standard deviation. A multiple linear regression, method of backward elimination was used to analyze potential risk factors for the number of pDDIs per patient. The statistical significance of the regression model was determined based on the values of $F$ (analysis of variance) and R2 (percentage of variability of the outcome explained by the model). The extent of the impact of potential risk factors on the number of pDDIs per patient was estimated by unstandardized B coefficients and 95\% confidence intervals (CI). The statistical analysis was done in the statistical program, SPSS version 18.

\section{RESULTS}

A total of 72 patients were included in this study and they were admitted to the hospital for the following reasons: (1) to clearly confirm a diagnosis of $\mathrm{PD},(2)$ to treat the exacerbation of PD or (3) to treat comorbidities, such as acute ischemic stroke (AIS) (14 patients - 19.44\%), cerebral small blood vessels disease (3 - 4.17\%), brain tumors (1 - 1.39\%) and spinal cord with peripheral nervous system disorders ( $8-11.11 \%)$. Most patients who were hospitalized in the neurological intensive care unit (NICU) were admitted for AIS while most of the other patients were treated at the department of neurodegenerative diseases. All patients with PD had bradykinesia. Non-tremor dominant type of PD was present in $60.0 \%$ of patients. At least one non-motor symptom or sign of PD was observed in 45 (62.5\%) patients. Each patient from the study group received at least one antiparkinsonian drug. Other demographic, clinical, and laboratory characteristics of patients as well as the characteristics of hospitalization and prescribed drugs are shown in the Table 1.

Micromedex ${ }^{\oplus}$ identified at least one pDDIs in $77.8 \%$ of patients. Majority of patients were exposed to moderate $(62.5 \%)$ and major (58.3\%) pDDIs. A total of 159 different pDDIs were classified as following: contraindicated $1(0.63 \%)$, major $67(42.14 \%)$, moderate $84(52.83 \%)$, and minor pDDIs 7 (4.40\%). Lexi-Interact detected pDDIs in $98.6 \%$ of patients. The highest proportions of patients were exposed to major (41.7\%) interactions and interactions that required therapy monitoring (93.1\%). A total of 310 pDDIs were detected with this checker in the following order: those to be avoided ( $\mathrm{x})$ - $2(0.64 \%)$, major interactions (d) 33 (10.64\%), interactions requiring therapy monitoring -(c) 247 (79.68\%), no action required (b) 27 (8.71\%), and unknown interactions - a $1(0.32 \%)$ Fair scientific evidence was shown for the majority of pDDIs (Micromedex $^{\infty}-68.1 \%$, Lexi-Interact - 93.1\%) (Table 2).Lexi-interact software detected significantly 
Table 1. Characteristics of the study sample of patients with Parkinson's disease

IQR - interquartile range NICU - neurological intensive care unit

PD - Parkinson's disease

\begin{tabular}{|c|c|}
\hline \multicolumn{2}{|c|}{ Demographic characteristics } \\
\hline Gender & Male $38(52.8 \%)$ Female 34 (47.2\%) \\
\hline Age $(\operatorname{median}(\mathrm{IQR})) ;$ Mean \pm SD & $73.0(67.25-79.5) ; 72.99 \pm 8.25$ \\
\hline \multicolumn{2}{|c|}{ Characteristics of hospitalization } \\
\hline Cause of hospitalization & $\begin{array}{l}\text { Diagnostics of PD } 15(20.8 \%) \\
\text { Exacerbation of PD } 31(43.1 \%) \\
\text { Other causes } 26(36.1 \%)\end{array}$ \\
\hline Department & NICU 17 (23.6\%) Others 55 (76.4\%) \\
\hline Length of hospitalization & $13.00(9.00-17.00) ; 14.29 \pm 7.86$ \\
\hline Number of diagnosis & $5.00(3.00-6.00) ; 5.03 \pm 2.39$ \\
\hline \multicolumn{2}{|c|}{ Clinical characteristics of patients with PD } \\
\hline Muscular rigidity & $59(90.8 \%)$ \\
\hline Postural instability & $46(68.7 \%)$ \\
\hline Rest tremor & $33(50.8 \%)$ \\
\hline Duration of PD (years) & $6.5(1.00-10.00) ; 6.75 \pm 5.66$ \\
\hline Tremor dominant PD & $26(40.0 \%)$ \\
\hline Age $(\operatorname{median}(\mathrm{IQR})) ;$ Mean \pm SD & $73.0(67.25-79.5) ; 72.99 \pm 8.25$ \\
\hline \multicolumn{2}{|c|}{ Non-motor symptoms of PD } \\
\hline Cognitive impairment & $23(31.9 \%)$ \\
\hline Pain & $16(22.2 \%)$ \\
\hline Falls & $15(20.8 \%)$ \\
\hline Urogenital dysfunction & 7 (9.7\%) \\
\hline Orthostatic hypotension & $6(8.3 \%)$ \\
\hline Sleep disorder & $5(6.9 \%)$ \\
\hline Constipation & $4(5.6 \%)$ \\
\hline Hallucination & $3(4.2 \%)$ \\
\hline
\end{tabular}

Comorbidities

\begin{tabular}{l|l}
\hline Hypertension & $46(63.9 \%)$ \\
\hline Cardiovascular disease & $30(41.7 \%)$ \\
\hline Diabetes mellitus 2 & $17(23.6 \%)$ \\
\hline Drug allergies & $14(19.4 \%)$ \\
\hline Thyroid disorder & $5(6.9 \%)$
\end{tabular}

Laboratory parameters

\begin{tabular}{l|l|}
\hline Hyperglycemia & $27(38.6 \%)$ \\
\hline High creatinine level & $17(24.6 \%)$ \\
\hline Urine ketone bodies & $12(21.1 \%)$
\end{tabular}

Characteristics of prescribed drugs

Number of prescribed drugs

7.00 (5.00-9.75); $7.61 \pm 3.30$

Receiving antiplatelet drugs

$48(66.7 \%)$

Receiving antidepressants

$28(38.9 \%)$

Receiving antipsychotics

$15(20.8 \%)$

Receiving antacids

$15(20.8 \%)$

Number of antiparkinsonian drugs

One - $31(43.1 \%)$

Two - $33(45.8 \%)$

Three - $8(11.1 \%)$

more pDDIs than Micromedex ${ }^{\oplus}(\chi 22=54.000, \quad$ according to severity and scientific evidence $\mathrm{p}<0.001)$. for both checkers are shown in the Table 3 . The contraindicated and pDDIs to be avoided 
are also shown in the Table 3 . Aspirin was the most frequent drug engaged in pDDIs with an occurrence of 38 (23.90\%) of all pDDIs), according to Micromedex ${ }^{\circ}$. According to LexiInteract checker, levodopa was the most frequent drug involved in pDDIs (37 (11.93\%)).

The following independent and confounding variables were entered into 6 models to test their effect on the rate of pDDIs: demographic characteristics (gender, age), characteristics of hospitalization (reason, ward, length of hospitalization), non-motor symptoms of PD (cognitive impairments), comorbidities (total number of patient's diagnosis, HTA or other cardiovascular diseases), laboratory parameters (serum creatinine level), characteristics of prescribed drugs (total number of drugs used simultaneously, use of antidepressants, antipsychotics and antiplatelet drugs, number of antiparkinsonian drugs, and drug allergy. The total number of pDDIs according to Micromedex ${ }^{\bullet}$ and Lexi-interact checker respectively was used as dependent variable in a linear regression model. Significant factors identified by the regression model based on Micromedex ${ }^{\otimes}$ findings $((\mathrm{R} 2=0.765$, $\mathrm{F}=70.376, \mathrm{p}<0.001)$ were number of drugs, number of antiparkinsonian drugs and HTA. The same factors were included in the model for the number of major pDDIs $(\mathrm{R} 2=0.584$, $\mathrm{F}=22.437, \mathrm{p}<0.001)$ and significance was found for number of drugs and number of pa- tient's diagnosis. When we examined the influence of these factors on the number of moderate $\mathrm{pDDIs}(\mathrm{R} 2=0.696, \mathrm{~F}=49.721, \mathrm{p}<0.001)$ number of drugs and use of antidepressants turned to have significant influence. Predictors of the total number of pDDIs according to Lexi-interact $(\mathrm{R} 2=0.849, \mathrm{~F}=57.974, \mathrm{p}=$ 0.000 ) were number of drugs, a ward where the patient was treated, number of comorbidities per patient, and use of antiplatelet drugs and antipsychotics. In the linear regression model for the number of major pDDIs ( $22=0.534, \mathrm{~F}$ $=18.364, \mathrm{p}<0.001)$, potential predictors were number of drugs and use of antipsychotics. For moderate $\mathrm{pDDIs}(\mathrm{R} 2=0.807, \mathrm{~F}=52.535$, $\mathrm{p}<0.001$ ), the important factors were number of drugs, hospitalization in the neurodegenerative ward, number of comorbidities and use of antiplatelet drugs. Unstandardized B coefficients, $95 \%$ CIs and $\mathrm{p}$ values were shown only for factors that were significant (Table 4).

\section{DISCUSSION}

The most commonly identified pDDIs with Micromedex ${ }^{\infty}$ were those that involved aspirin (with bisoprolol, sertraline, perindopril). Only one contraindicated pDDI (pCDDI) was found, i.e. amantadine with potassium chloride. Predictor of pDDIs in general was number of drugs, while use of antidepressants was significant risk factor for major pDDIs. The

\begin{tabular}{|c|c|c|c|}
\hline \multicolumn{4}{|c|}{ Micromedex ${ }^{\circledast}$} \\
\hline $\mathrm{pDDI}^{1}$ & $\begin{array}{l}\text { Number and } \\
\% \text { of patients }\end{array}$ & $\begin{array}{c}\text { Median } \\
\left(I^{2} R^{2}\right)\end{array}$ & $\begin{array}{l}\text { Mean } \\
\left( \pm \mathrm{SD}^{3}\right)\end{array}$ \\
\hline $\begin{array}{l}\text { Number } \\
\text { of pDDls }\end{array}$ & $\begin{array}{l}56 \\
(77.8 \%)\end{array}$ & $\begin{array}{l}3.00 \\
(1.00-6.75)\end{array}$ & $\begin{array}{l}4.32 \\
(4.99)\end{array}$ \\
\hline pCDDls ${ }^{4}$ & $\begin{array}{l}3 \\
(4.2 \%)\end{array}$ & $\begin{array}{l}0.00 \\
(0.00-0.00)\end{array}$ & $\begin{array}{l}0.4 \\
(0.20)\end{array}$ \\
\hline Major & $\begin{array}{l}42 \\
(58.3 \%)\end{array}$ & $\begin{array}{l}1.00 \\
(0.00-3.00)\end{array}$ & $\begin{array}{l}1.76 \\
(2.43)\end{array}$ \\
\hline Moderate & $\begin{array}{l}45 \\
(62.5 \%)\end{array}$ & $\begin{array}{l}1.00 \\
(0.00-3.00)\end{array}$ & $\begin{array}{l}2.35 \\
(3.04)\end{array}$ \\
\hline Minor & $\begin{array}{l}9 \\
(12.5 \%)\end{array}$ & $\begin{array}{l}0.00 \\
(0.00-0.00)\end{array}$ & $\begin{array}{l}0.15 \\
(0.43)\end{array}$ \\
\hline Excellent & $\begin{array}{l}22 \\
(30.6 \%)\end{array}$ & $\begin{array}{l}0.00 \\
(0.00-1.00)\end{array}$ & $\begin{array}{l}0.47 \\
(0.87)\end{array}$ \\
\hline Good & $\begin{array}{l}41 \\
(56.9 \%)\end{array}$ & $\begin{array}{l}1.00 \\
(0.00-2.75)\end{array}$ & $\begin{array}{l}1.57 \\
(2.01)\end{array}$ \\
\hline Fair & $\begin{array}{l}49 \\
(68.1 \%)\end{array}$ & $\begin{array}{l}1.00 \\
(0.00-3.00)\end{array}$ & $\begin{array}{l}2.29 \\
(2.87)\end{array}$ \\
\hline
\end{tabular}

\begin{tabular}{|c|c|c|c|}
\hline \multicolumn{4}{|c|}{ Lexi-Interact } \\
\hline pDDI & $\begin{array}{l}\text { Number and } \\
\% \text { of patients }\end{array}$ & $\begin{array}{l}\text { Median } \\
\text { (IQR) }\end{array}$ & $\begin{array}{l}\text { Mean } \\
\pm S D\end{array}$ \\
\hline $\begin{array}{l}\text { Number of } \\
\text { pDDls }\end{array}$ & $\begin{array}{l}71 \\
(98.6 \%)\end{array}$ & $\begin{array}{l}8.5 \\
(4.00-17.50)\end{array}$ & $\begin{array}{l}11.64 \\
(9.45)\end{array}$ \\
\hline Avoid (x) & $\begin{array}{l}4 \\
(5.6 \%)\end{array}$ & $\begin{array}{l}0.00 \\
(0.00-0.00)\end{array}$ & $\begin{array}{l}0.6 \\
(0.231)\end{array}$ \\
\hline Major (d) & $\begin{array}{l}30 \\
(41.7 \%)\end{array}$ & $\begin{array}{l}0.00 \\
(0.00-1.00)\end{array}$ & $\begin{array}{l}0.79 \\
(1.21)\end{array}$ \\
\hline $\begin{array}{l}\text { Monitor } \\
\text { therapy (c) }\end{array}$ & $\begin{array}{l}67 \\
(93.1 \%)\end{array}$ & $\begin{array}{l}7.00 \\
(3.25-14.00)\end{array}$ & $\begin{array}{l}9.64 \\
(8.14)\end{array}$ \\
\hline No action (b) & $\begin{array}{l}50 \\
(69.4 \%)\end{array}$ & $\begin{array}{l}1.00 \\
(0.00-1.00)\end{array}$ & $\begin{array}{l}1.11 \\
(1.18)\end{array}$ \\
\hline $\begin{array}{c}\text { No known } \\
\text { interaction (a) }\end{array}$ & $\begin{array}{l}3 \\
(4.2 \%)\end{array}$ & $\begin{array}{l}0.00 \\
(0.00-0.00)\end{array}$ & $\begin{array}{l}0.4 \\
(0.20)\end{array}$ \\
\hline Excellent & $\begin{array}{l}18 \\
(25.0 \%)\end{array}$ & $\begin{array}{l}0.00 \\
(0.00-0.75)\end{array}$ & $\begin{array}{l}0.40 \\
(0.80)\end{array}$ \\
\hline Good & $\begin{array}{l}39 \\
(54.2 \%)\end{array}$ & $\begin{array}{l}0.0 \\
(0.00-2.00)\end{array}$ & $\begin{array}{l}1.14 \\
(1.48)\end{array}$ \\
\hline Fair & $\begin{array}{l}67 \\
(93.1 \%)\end{array}$ & $\begin{array}{l}7.0 \\
(3.00-13.00)\end{array}$ & $\begin{array}{l}9.18 \\
(7.75)\end{array}$ \\
\hline Poor & $\begin{array}{l}44 \\
(61.1 \%)\end{array}$ & $\begin{array}{l}1.00 \\
(0.00-1.00)\end{array}$ & $\begin{array}{l}0.85 \\
(0.90)\end{array}$ \\
\hline
\end{tabular}

Table 2. Potential drug-drug interactions detected by $\mathrm{Mi}$ cromedex $^{\circledast}$ and Lexi-Interact checkers

1 potential drug-drug interactions

2 interquartile range

${ }^{3}$ standard deviation

4 potentially contraindicated drug-drug interactions 
Table 3. Examples of the most frequent potential drug-drug interactions detected by Micromedex ${ }^{\circledR}$ and Lexi-Interact

1 potential drug-drug interactions

\begin{tabular}{|l|l|l|}
\hline \multicolumn{3}{|c|}{ Micromedex } \\
\hline \multicolumn{3}{|c|}{ The most frequent pDDIs } \\
\hline \multicolumn{1}{|c|}{ Drug 1-Drug 2} & $\begin{array}{l}\text { Scientific } \\
\text { evidence }\end{array}$ & $\begin{array}{c}\text { No and \% } \\
\text { of patients }\end{array}$ \\
\hline Aspirin-Bisoprolol & Good & $20(27.78)$ \\
\hline Aspirin-Sertraline & Excellent & $13(18.05)$ \\
\hline Aspirin-Perindopril & Fair & $12(16.7)$ \\
\hline Aspirin-Furosemide & Good & $11(15.28)$ \\
\hline Aspirin-Metformin & Fair & $9(12.5)$ \\
\hline Bisoprolol-Metformin & Good & $6(8.33)$ \\
\hline Metformin-Perindopril & Fair & $6(8.33)$ \\
\hline Aspirin-Diclofenac & Fair & $6(8.33)$ \\
\hline \multicolumn{2}{|c|}{ Contraindicated pDDI } \\
\hline
\end{tabular}

Amantadine-Potassium chloride

Fair $\quad 3(4.17)$

\section{Major pDDls}

\begin{tabular}{|l|l|l|}
\hline Aspirin-Sertraline & Excellent & $13(18.05)$ \\
\hline Aspirin-Furosemide & Good & $11(15.28)$ \\
\hline Aspirin-Metformin & Fair & $9(12.5)$
\end{tabular}

\section{Moderate pDDls}

\begin{tabular}{|l|l|l|}
\hline Aspirin-Bisoprolol & Good & $20(27.78)$ \\
\hline Aspirin-Perindopril & Fair & $12(16.7)$ \\
\hline Bisoprolol-Metformin & Good & $6(8.33)$ \\
\hline Metformin-Perindopril & Fair & $6(8.33)$ \\
\hline
\end{tabular}

Minor pDDls

Aspirin-Ranitidine
Cyanocobalamin-Ascor-
bic acid

Folic-Ascorbic acid

\begin{tabular}{ll} 
Excellent & $3(4.17)$ \\
\hline Good & $2(2.78)$ \\
\hline Good & $2(2.78)$
\end{tabular}

most frequently identified pDDIs with LexiInteract were levodopa/ bisoprolol, levodopa/ clonazepam and levodopa/perindopril). Potassium chloride participated in 2 pCDDIs (with clozapine and risperidone). Total number of drugs, number of comorbidities, hospitalization at the neurodegenerative ward, and use of antipsychotics were identified as relevant predictors of pDDIs.

A large number of studies investigated prevalence and risk factors for the occurrence of pDDIs, but as mentioned previously, none of them was devoted to patients with PD so far. The frequency of potential interactions among neurological patients in the literature ranged from $35,5 \%$ (16) to $96 \%$ [17], which is consistent with our study. Also, predictors of number of interactions per patient in our study almost coincide with the results of the

\begin{tabular}{|c|c|c|}
\hline \multicolumn{3}{|c|}{ Lexi-Interact } \\
\hline \multicolumn{3}{|c|}{ The most frequent pDDls } \\
\hline Drug 1-Drug 2 & $\begin{array}{l}\text { Scientific } \\
\text { evidence }\end{array}$ & $\begin{array}{l}\text { No and } \% \\
\text { of patients }\end{array}$ \\
\hline Levodopa-Bisoprolol & Fair & $26(36.11)$ \\
\hline Levodopa-Clonazepam & Poor & $20(27.78)$ \\
\hline Levodopa-Perindopril & Fair & $15(20.83)$ \\
\hline Levodopa-Ropinirol & Fair & $13(18.05)$ \\
\hline Aspirin-Sertraline & Fair & $13(18.05)$ \\
\hline Levodopa-Amlodipine & Fair & $13(18.05)$ \\
\hline Levodopa-Furosemide & Fair & $12(16.7)$ \\
\hline Levodopa-Lorazepam & Poor & $12(16.7)$ \\
\hline \multicolumn{3}{|c|}{ Avoid (x) } \\
\hline $\begin{array}{l}\text { Potassium chloride- } \\
\text { Clozapine }\end{array}$ & Fair & $3(4.17)$ \\
\hline $\begin{array}{l}\text { Potassium chloride- } \\
\text { Risperidone }\end{array}$ & Fair & $1(1.39)$ \\
\hline \multicolumn{3}{|c|}{ Major (d) } \\
\hline Levodopa-Clozapine & Excellent & $10(13.89)$ \\
\hline Aspirin-Diclofenac & Good & $5(6.94)$ \\
\hline \multicolumn{3}{|c|}{ Monitor therapy (c) } \\
\hline Levodopa-Bisoprolol & Fair & $26(36.11)$ \\
\hline Levodopa-Perindopril & Fair & $15(20.83)$ \\
\hline Levodopa-Ropinirol & Fair & $13(18.05)$ \\
\hline Aspirin-Sertraline & Fair & $13(18.05)$ \\
\hline Levodopa-Amlodipine & Fair & $13(18.05)$ \\
\hline \multicolumn{3}{|c|}{ No action (b) } \\
\hline Levodopa-Clonazepam & Poor & $20(27.78)$ \\
\hline Levodopa-Lorazepam & Poor & $12(16.7)$ \\
\hline
\end{tabular}

other authors. Higher number of prescribed medications and comorbidities increased the risk of pDDIs both among neurological patients $[5,16,17]$ and patients treated for other diseases $[15,18]$. Certain drug groups, such as antiplatelet drugs [19] and antipsychotics [20], showed high potential for drug-drug interactions due to their specific pharmacokinetic and pharmacodynamic profile. This could explain our results where use of antipsychotics was associated with the occurrence of major pDDIs detected by Lexi-Interact tool, while the use of antiplatelet drugs contributed to the major pDDIs identified by Micromedex ${ }^{\circ}$.

Psychosis is one of the most common non-motor disorders in PD patients, which occurs in a small number of patients as a consequence of the adverse effects of antiparkinsonian drugs [21]. It is well-known 


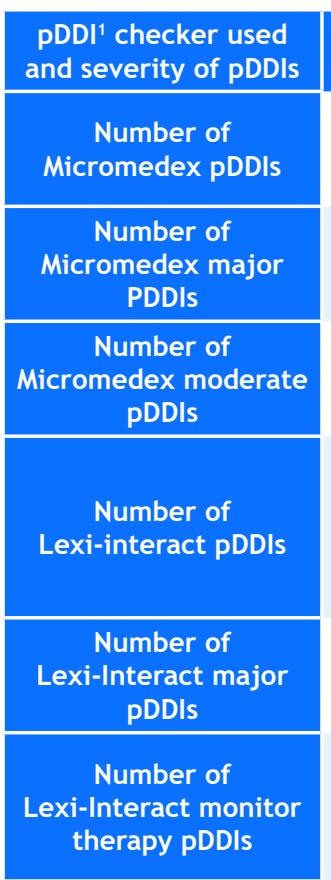

\begin{tabular}{|l|c|c|c|}
\hline \multicolumn{1}{|c|}{ Predictor variable } & $\begin{array}{c}\text { Unstandardized } \\
\text { coefficients }\end{array}$ & $\mathrm{Cl}^{2} \mathbf{( 9 5 \% )}$ & Sig. $\mathbf{p}$ \\
\hline $\begin{array}{l}\text { Number of drugs } \\
\text { Number of antiparkinsonian drug }\end{array}$ & 1.389 & $1.190-1.587$ & 0.000 \\
\hline HTA3 & -0.901 & $-1.780--0.023$ & 0.044 \\
\hline Number of drugs & -1.351 & $-2.564--0.138$ & 0.030 \\
\hline Antidepressants & 0.495 & $0.348-0.642$ & 0.000 \\
\hline Number of drugs & 1.021 & $0.182-1.859$ & 0.018 \\
\hline Antidepressants & & & \\
\hline Number of drugs & 0.767 & $0.641-0.894$ & 0.000 \\
\hline $\begin{array}{l}\text { Department } \\
\text { Number of diagnosis }\end{array}$ & -1.114 & $-1.979--0.250$ & 0.012 \\
\hline $\begin{array}{l}\text { Antiplatelet } \\
\text { Antipsychotics }\end{array}$ & 2.276 & $1.925-2.627$ & 0.000 \\
\hline Number of drugs & -4.430 & $-6.819--1.988$ & 0.001 \\
\hline Antipsychotics & 0.669 & $0.173-1.165$ & 0.009 \\
\hline $\begin{array}{l}\text { Number of drugs } \\
\text { Department }\end{array}$ & -2.681 & $-4.841--0.521$ & 0.016 \\
\hline $\begin{array}{l}\text { Number of diagnosis } \\
\text { Antiplatelet }\end{array}$ & 3.163 & $0.872-5.455$ & 0.008 \\
\hline & 0.158 & $0.084-0.232$ & 0.000 \\
\hline & 1.742 & $1.221-2.264$ & 0.000 \\
\hline & 1.801 & $1.466-2.136$ & 0.000 \\
\hline & -3.160 & $-5.259--1.061$ & 0.004 \\
\hline & 0.520 & $0.055-0.985$ & 0.029 \\
\hline & -2.074 & $-4.019--0.130$ & 0.037 \\
\hline
\end{tabular}

that typical antipsychotics, being predominantly antagonists of the dopamine receptors are contraindicated for use in patients with PD [22]. Therefore, atypical antipsychotics with marked antagonistic effect on 5-HT2A serotonin receptors, such as clozapine and quetiapine are being used today to treat psychosis in PD patients [21]. Several studies indicate that clozapine effectively treats psychosis in patients with PD and even improves tremor without exacerbating other motor symptoms of the disease $[23,24]$. However, rare cases of worsening of the motor symptoms of the disease have been reported following clozapine administration [25]. This impairment is due to antagonistic effect of clozapine on dopamine receptors (although less intense than typical antipsychotics, clozapine binds to dopamine receptors), which weakens the effect of levodopa; this happened potentially in 10 patients from our study who used clozapine and levodopa simultaneously. In addition, regular blood counts are required in patients using clozapine due the neutropenia that often accompanies its use [24]. Therefore, the first step in treating psychosis in patients with PD should be to reduce the dose of existing antiparkinsonian drugs to the minimum effective, and only then to administer atypical antipsychotics [21].

By analyzing the pDDIs of our patients in Lexi-Interact tool, interactions between levodopa and antihypertensive drugs were particularly frequent. Concomitant use of levodopa with antihypertensive drugs increases the risk of orthostatic hypotension. Although interactions of levodopa with drugs from all major antihypertensive drug groups (diuretics, calcium antagonists, and angioare categorized as moderate, Bitner et al [12] believe that the first-line therapy of hypertension in PD should be based ACE inhibitors or beta-blockers, because of the lowest risk for hypotension.

Micromedex ${ }^{\odot}$ and Lexi-Interact checkers are among the most sensitive and specific tools for detecting and evaluating of pDDIs $[26,27]$. It is known that there are important differences between various types of checkers $[27,28]$. We also have to emphasize significant differences between Micromedex ${ }^{\circ}$ and Lexi-Interact online checkers in detecting potential interactions among patients with Parkinson's disease. Much higher number of potential interactions was detected by means of Lexi-Interaction checker $(310 \mathrm{pD}$ DIs) compared to Micromedex (159 pDDIs). The pDDIs of levodopa with antihypertensive drugs detected by Lexi-Interact were not detected using Micromedex ${ }^{\oplus}$. Furthermore, only $10.64 \%$ of the interactions detected by LexiInteract were major severity, while major interactions in Micromedex ${ }^{\circ}$ were more prevalent $(42,14 \%)$. Significant differences were also observed previously after comparing Microtensin-converting-enzyme (ACE) inhibitors)
Table 4. Predictors of pDDIs discovered by multivariate linear regression

1 potential drug-drug interactions

${ }^{2}$ confidence interval

${ }^{3}$ hypertension 
medex $^{\otimes}$ with Epocrates and Medscape interaction checkers [15]. Although each of these screening tools has satisfactory sensitivity and specificity, there is a need for the combined use of two or more checkers to avoid misdetection of pDDIs.

Our study was retrospective, so limited number of available variables, could have influenced the results. The study was singlecentered and with relatively small number of patients, which limits generalizability of the results. Only hospitalized patients were included in the study, and their therapy was influenced by the availability of drugs at the hospital's pharmacy, introducing certain degree of bias.

\section{CONCLUSION}

This study revealed high frequency of pDDIs in patients with PD. Performance of the two online checkers used in the study was very different, underlying necessity to use them both, otherwise some important pDDIs could be missed. The main predictors of pDDIs were total number of drugs, number of comorbidities, hospitalization at the neurodegenerative ward and therapy with antidepressants or antipsychotics. Neurologists should pay special attention when deciding whether to administer new drug to a PD patient with multiple comorbidities, hospitalized in a neurodegenerative ward and/or taking antidepressant or antipsychotic drugs.

\section{ACKNOWLEDGEMENT}

This study was partially supported by the Grant No 175007 given by Serbian Ministry of Education, Science and Technological Development.

\section{CONFLICT OF INTEREST}

All authors declare no conflict of interest.

\section{REFERENCES}

1. Radhakrishnan DM, Goyal V. Parkinson's disease: A review. Neurol India 2018;66(Supplement):S26S35. doi: 10.4103/0028-3886.226451.

2. Lai BCL, Tsui JKC. Epidemiology of Parkinson'sdisease. BCMJ 2001;43(3):133-37.doi:

3. Armstrong MA, Okun MS. Diagnosis and Treatment of Parkinson Disease. JAMA 2020;323(6):548-60. doi: $10.1001 /$ jama.2019.22360

4. Grimes D, Fitzpatrick M, Gordon J, et al. Canadian guideline for Parkinson disease. CMAJ 2019;191(36):E989-E1004. doi: 10.1503/ cmaj.181504.

5. Aleksic DZ, Jankovic SM, Mlosavljevic MN, et al. Potential Drug-drug Interactions in Acute Ischemic Stroke Patients at the Neurological Intensive Care Unit. Open Med (Wars) 2019;14:813-26. doi:10.1515/med-2019-0093

6. Truven Health Analtytics LLC, Micromedex® Solutions. [online]. Dostupné z URL: https: / / www. micromedexsolutions.com/home/dispatch/PFDefaultActionld/pf.LoginAction/ssl/true?redirected=true. Accessed 08 December2020.

7. Lexi-Comp OnlineTM, Pediatric Lexi-Drugs OnlineTM, Hudson, Ohio: Lexi-Comp, Inc. [online]. Available at: www.lexi.com/institutions/products/ online/. Accessed 08 December2020.

8. Medscape. Multi-Drug Interaction checker. [online]. Available at: http://reference.medscape. com/druginteractionchecker. Accessed 08 December2020.

9. Epocrates, Inc. Interaction Checker. [online]. Availeble at: https://online.epocrates.com/interaction-check. Accessed 08 December2020.

10. Haefeli WE. Drug-drug interactions with levodopa modulating treatment responses in Parkinson's disease. J NEUROL 2007;254[Suppl4]:IV/29-IV-36. doi: $10.1007 / \mathrm{s} 00415-007-4006-\mathrm{x}$.

11. Teychenne PF, Calne DB, Lewis PJ, et al. Interactions of levodopa with inhibitors of monoamine oxidase and L-aromatic amino acid decarboxylase. ClinPharmacolTher 1975;18(3):273-277. doi: $10.1002 /$ cpt1975183273.

12. Bitner A,Zalewski P, Klawe JJ, et al. Drug Interactions in Parkinson's Disease: Safety of Pharmacotherapy for Arterial Hypertension. Drugs Real World Outcomes 2015;2(1):1-12.doi:10.1007/s40801-0150008-7

13. Montastruc JL, Chamontin B, Senard JM, et al. Pseudophaeochromocytoma in parkinsonian patient treated with fluoxetine plus selegiline. Lancet 1993;341:555.doi: 10.1016/0140-6736(93)90313-6.

14. Hinds NP, Hillier CEM, Wiles CM. Possible serotonin syndrome arising from an interaction between nortriptyline and selegiline in a lady with parkinsonism. J Neurol 2000;247:811.doi: 10.1007/ s004150070101.

15. Janković SM, Pejčić AV, Milosavljević MN, et al. Risk factors for potential drug-drug interactions in intensive care unit patients. J Crit Care 2018;43:16. doi: 10.1016/j.jcrc.2017.08.021.

16. Namazi S, Pourhatami S, Borhani-Haghighi A, et al. Incidence of Potential Drug-Drug Interaction and Related Factors in Hospitalized Neurological 
Patients in two Iranian Teaching Hospitals. Iran J Med Sci 2014;39(6):515-21.

17. Zafar R, Chisti KA, Zahoor M. Potential drugdrug interactions in the neurology ward of a tertiary care hospital in Peshawar, Pakistan. TROP J PHARM RES 2017;16(10): 2521-6.doi: 10.4314/tjpr. v16i10.28.

18. Mousavi S, Ghanbari G. Potential drug-drug interactions among hospitalized patients in a developing country. Caspian J Intern Med 2017; 8(4):2828. doi: $10.22088 /$ cjim.8.4.282.

19. Wang ZY, Chen M, Zhu LL,et al. Pharmacokinetic drug interactions with clopidogrel: updated review and risk management in combination therapy. TherClin Risk Manag 2015;11:449-67. doi: 10.2147/ TCRM.S80437.

20. Kennedy WK, Jann MW, Kutscher EC. Clinically significant drug interactions with atypical antipsychotics. CNS Drugs 2013;27(12):1021-48. doi: 10.1007/s40263-013-0114-6.

21. Taddei RN, Cankaya S, Dhaliwal S, et al. Management of Psychosis in Parkinson's Disease: Emphasizing Clinical Subtypes and Pathophysiological Mechanisms of the Condition. Parkinsons Dis 2017; 2017:3256542. doi: 10.1155/2017/3256542.

22. Jost WH, Brück C. Drug interactions in the treatment of Parkinson's disease. J Neurol 2002; 249 Suppl 3:III/24-III/29. doi: 10.1007/s00415-0021305-0.

23. Klein C, Gordon J, Pollak L, et al. Clozapine in Parkinson's disease psychosis: 5-year follow-up review. ClinNeuropharmacol 2003;26(1):8-11. doi: 10.1097/00002826-200301000-00003.

24. Thomas AA, Friedman JH. Current use of clozapine in Parkinson disease and related disorders. ClinNeuropharmacol 2010;33(1):14-6. doi: 10.1097/ WNF.0b013e3181c47168.

25. Pollak P, Tison F, Rascol O, et al. Clozapine in drug induced psychosis in Parkinson's disease: a randomised, placebo controlled study with open follow up. J NeurolNeurosurg Psychiatry 2004;75:689. 95.doi: 10.1136/jnnp.2003.029868.

26. Patel RI, Beckett RD. Evaluation of resources for analyzing drug interactions. J Med LibrAssoc 2016;104(4):290-5. doi:10.3163/15365050.104.4.007

27. Clauson KA, Marsh WA, Polen HH, et al. Clinical decision support tools: analysis of online drug information databases. BMC Med Inform DecisMak 2007;7:7. doi:10.1186/1472-6947-7-7

28. Grizzle AJ, Horn J, Collins C, et al. Identifying Common Methods Used by Drug Interaction Experts for Finding Evidence About Potential DrugDrug Interactions Based Survey. J Med Internet Res 2019;21(1):e11182.doi: 10.2196/11182. 


\title{
Učestalost i prediktori potencijalnih interakcija između lekova kod hospitalizovanih pacijenata sa Parkinsonovom bolešću
}

\author{
Dejan Z. Aleksić1, Srđan M. Stefanović2, Miloš N. Milosavljevićs \\ Jovana Z. Milosavljevićc ${ }^{4}$, Slobodan M. Janković ${ }^{3}$ \\ ${ }^{1}$ Katedra za neurologiju, Fakultet medicinskih nauka, Univerzitet u Kragujevcu, Kragujevac, Srbija \\ Katedra za farmaciju, Fakultet medicinskih nauka, Univerzitet u Kragujevcu, Kragujevac, Srbija \\ Katedra za farmakologiju i toksikologiju, Fakultet medicinskih nauka, Univerzitet u Kragujevcu, Kragu- \\ jevac, Srbija \\ ${ }^{4}$ Katedra za anatomiju, Fakultet medicinskih nauka, Univerzitet u Kragujevcu, Kragujevac, Serbia
}

\section{KRATAK SADRŽAJ}

Uvod: Bolesnici sa Parkinsonovom bolešću su u proseku izloženi većem broju lekova u odnosu na ostale starije osobe. Levodopa, koja predstavlja glavni oslonac u terapiji Parkinsonove bolesti, često stupa u interakcije sa brojnim lekovima.

Cilj: Cilj ove studije je bio da se identifikuju prediktori potencijalnih interakcija između lekova (PIL) kod hospitalizovanih pacijenata sa Parkinsonovom bolešću (PB).

Metodologija: Ovo je bila akademska retrospektivna studija preseka na pacijentima sa Parkinsonovom bolešću koji su bili hospitalizovani na Klinici za neurologiju, Kliničkog centra u Kragujevcu. Analizirani su medicinski kartoni pacijenata koji su bili hospitalizovani u periodu od 01.01.2017.- 31.12.2019. godine. PIL su identifikovane pomoću Micromedex i Lexi-Interact onlajn softvera, a metode multivarijantne regresije su korišćene za otkrivanje prediktora za pojavu PIL-ova.

Rezultati: Micromedex-om je otkriveno 160 različitih PIL-ova kod 77,8\% od ukupno 72 pacijenta sa PB. Najčešće PIL su bile one koje su uključivale aspirin (sa bisoprololom, sertralinom i perindoprilom). Prediktori za pojavu svih oblika PIL-ova bili su ukupan broj lekova, dok je upotreba antidepresiva bila značajan faktor rizika za teške PIL. Primenom Lexi-Interact-a otkriveno je 310 različitih PIL-ova kod 98,6\% pacijenata. Tri najčešće PIL uključivale su levodopu (sa bisoprololom, klonazepamom i perindoprilom). Ukupan broj lekova, broj komorbiditeta, hospitalizacija na odeljenju za neurogenerativne bolesti i upotreba antipsihotika identifikovani su kao relevantni prediktori za pojavu PIL-ova. Lexi-Interact softver je otkrio statistički značajno više PIL-ova od Micromedexa $(\mathrm{p}<0,001)$.

Zaključak: Neurolozi treba da obrate naročitu pažnju kada se odlučuju da li će primeniti novi lek pacijentu sa PB koji ima višestruke komorbiditete, koji je hospitalizovan na odeljenju za neurodegenerativne bolesti i/ili uzima antidepresive ili antipsihotike.

Ključne reči: Parkinsonova bolest, potencijalne interakcije između lekova, prediktori, Micormedex, Lexi-Interact 